\title{
The Archaic Period in East Texas and Surrounding Areas
}

Timothy K. Perttula

Heritage Research Center, Stephen F. Austin State University

Follow this and additional works at: https://scholarworks.sfasu.edu/ita

Part of the American Material Culture Commons, Archaeological Anthropology Commons, Environmental Studies Commons, Other American Studies Commons, Other Arts and Humanities Commons, Other History of Art, Architecture, and Archaeology Commons, and the United States History Commons

Tell us how this article helped you.

This Article is brought to you for free and open access by the Center for Regional Heritage Research at SFA ScholarWorks. It has been accepted for inclusion in Index of Texas Archaeology: Open Access Gray Literature from the Lone Star State by an authorized editor of SFA ScholarWorks. For more information, please contact cdsscholarworks@sfasu.edu. 


\section{The Archaic Period in East Texas and Surrounding Areas \\ Creative Commons License \\ (c) $($ ) (8) 8}

This work is licensed under a Creative Commons Attribution-NonCommercial 4.0 International License 


\section{THE ARCHAIC PERIOD IN EAST TEXAS AND SURROUNDING AREAS}

\section{Timothy K. Perttula}

It is a tradition of the East Texas Archeological Conference to focus the afternoon portion of the meeting on a particular archeological theme or topic, and ask archaeologists active in the field to come talk at the Conference on these specific themes or topics and then participate in a panel discussion. We have done that with panels on site protection efforts in 1993 (Perttula 1993:1-14), the origins of mound-building in the Caddoan area in 1994 (see Schambach 1997), the Paleoindian archaeological record in 1995, and the Caddoan people and missions in 1996 (Perttula 1996:20, 69-85).

In 1997, the focus of the panel was on "The Archaic Period in East Texas and Surrounding Areas." Panelists included Maynard B. Cliff (Geo-Marine, Inc., Plano), James E. Corbin (Stephen F. Austin University, Nacogdoches), Ross C. Fields (Prewitt and Associates, Inc., Austin), and Jeffery Girard (Northwestern State University, Natchitoches), along with Don G. Wyckoff (Oklahoma Museum of Natural History, Norman). Wyckoff began the afternoon program with a talk on the Calf Creek Culture (see Wyckoff and Shockey 1994, 1995), and the other panelists spoke for 10 minutes each on any topic or theme of their choice concerning the Archaic and hunter-gatherer archaeological record in East Texas and surrounding areas:

- Ross C. Fields, Why Don't We Know More About the Archaic Period in Northeast Texas?

- Maynard B. Cliff, Not With a Bang, but a Whimper: The End of the Archaic in Northeast Texas

- James E. Corbin, Friley, Catahoula, and Sandy Paste Ceramics: Reflections on the Early Ceramic Period and the Terminal Archaic in South Central East Texas

- Jeff Girard, Stone Tool and Raw Material Variation on the Eastern Side of Caddo Lake

Fields', Maynard Cliff's, and Corbin's presentations are published in this volume of the Journal of Northeast Texas Archaeology.

The papers and panel discussion on the Archaic period (ca. 8000-100 B.C.) were wideranging and incisive, but it is clear that compared to other prehistoric periods in Northeast Texas, and by comparison to much of the Southeastern U.S. (see Anderson and Sassaman 1996; Sassaman and Anderson 1996a), we know relatively little about the Archaic archaeological period in the region. The lack of context on Archaic archaeological sites, and the poor preservation of features and animal/plant remains, are key reasons behind the problems archacologists face in interpreting and better understanding Archaic huntergatherer lifeways in Northeast Texas.

Using data on approximately 3700 Archaic period sites in Louisiana and Arkansas, Anderson (1996) has made a number of interesting observations about changes in Archaic settlement that may have relevance to our understanding of the East Texas archaeological record, particularly about how varied the cultural landscape was then, and that there were a range of cultural adaptations. Future research on the Archaic period in East Texas should explicitly evaluate these findings. He noted the following major trends and changes in settlement:

1. A low incidence of Early Archaic (ca. $8000-6000$ B.C.) sites, with the sites tending to occur near major drainages (such as the Red River) or in 
resource-rich areas (i.e., along escarpment areas of the Ouachita Mountains and Ozark Highlands);

2. There are concentrations of Middle Archaic (ca. 6000-3000/2000 B.C.) sites along the upper Red River, the central Sabine River, and interior uplands (away from major drainages) that may be the product of highly mobile foraging adaptations (of small and organizationally uncomplicated groups) with expedient lithic technologies. The sites of this period tend to occur along the major drainages; and

3. Late Archaic sites (ca. $3000 / 2000$ B.C. -100 B.C.) occur widely, suggesting a moderate to extensive use of almost every part of the region; this may reflect higher population levels. There are major site concentrations along streams such as the Red and Little rivers in Arkansas, in the Ozarks, and on the upper Arkansas River.

While these broad trends may accurately depict Archaic period settlement changes, there is still much we can learn about the Archaic peoples that lived in Northeast Texas and surrounding areas by looking in detail, for example, at the archaeological record as a cultural and geographic landscape (see Corbin, this volume). Changes in the use of local versus non-local raw materials hold hints to Archaic mobility patterns, lithic technologies, as well as to participation in wide-ranging trade and interaction networks. Significant shifts over time in the use and settlement of different parts of the landscape, even on sites that lack good contextual integrity, may be associated with important changes in the adoption and use of ceramics and the increasing cultivation and consumption of seeds, maize, and other tropical cultigens that became manifest during the prehistoric Caddoan tradition. Other research problems and themes that may be productive can consider environments; technology; subsistence and health; settlements; and regional interaction and organization at regional, site-specific, synchronic, and diachronic views (cf. Sassaman and Anderson 1996a).

We face a considerable interpretive challenge in the years ahead in untapping and expanding our knowledge about the prehistoric hunter-gatherers that lived in Northeast Texas for millennia. In tackling the Archaic period archaeological record, I pose the following research problems, research strategies, and questions for consideration:

- What broad group affiliations do we think the Archaic period peoples in East Texas had with other groups?

- When does the Archaic period date from? How can we improve our chronological understanding?

- Was there interaction, trade, and contact principally with Southeastern groups to the east, or with Southern Plains groups, coastal Texas groups, etc.?

- What are the criteria we use to recognize and define Archaic period sites (such as chipped projectile point technology and style, or changes in economic orientation), and are there other useful criteria that should be considered?

- What might we learn about Archaic settlements through raw site and archaeological component data (cf. Anderson 1996:157-171), collections documentation (i.e., projectile point distributional data, as with Anderson's work with Paleoindian projectile points [Anderson and Sassaman 1996:Figure 3.1 and 3.3], and site distributional maps by period? What is the value of regional settlement mapping?

- We need an integrated regional research perspective, as has been so successfully carried through in much of the Southeast U.S. (Anderson 1996; Anderson and Sassaman 
1996; Sassaman and Anderson 1996a, 1996b). 'This perspective has focused on examining the diversity of archaeological record (meaning artifact assemblages, tool designs, raw material use, and site distributions) across broad areas at particular times because cultural systems in the past often had an expansive geographic scale, and then attempting to explain that diversity with respect to what local adaptations were, and as responses to regional-scale processes of interaction.

- What should be the main focus of this kind of regional research effort on the Archaic period in East Texas?

\section{REFERENCES CITED}

Anderson, D. G.

1996 Approaches to Modeling Regional Settlement in the Archaic Period Southeast. In Archaeology of the Mid-Holocene Southeast, edited by K. E. Sassaman and D. G. Anderson, pp. 157-176. University Press of Florida, Gainesville.

Anderson, D. G. and K. E. Sassaman (editors)

1996 The Paleoindian and Early Archaic Southeast. University of Alabama Press, Tuscaloosa.

Perttula, T. K. (compiler)

1993 Diminishing Caddoan Resources in East Texas. Notes on Northeast Texas Archaeology 1:1-14.

1996 Two Worlds Meet: The Caddoan People and Missions. Journal of Northeast Texas Archaeology 7:20, 69-85.

Sassaman, K. E. and D. G. Anderson (editors)

1996a Archaeology of the Mid-Holocene Southeast. University Press of Florida, Gainesville.

1996b The Need for a Regional Perspective. In The Paleoindian and Early Archaic Southeast, edited by D. G. Anderson and K. E. Sassaman, pp. 215-221. University of Alabama Press, Tuscaloosa.

Schambach, F. F.

1997 The Development of the Burial Mound Tradition in the Caddo Area. Journal of Northeast Texas Archaeology 9:53-72.

Wyckoff, D. G. and D. Shockey (editors)

1994 Bulletin of the Oklahoma Anthropological Society, Volume XL for 1991. Oklahoma Anthropological Society, Norman.

1995 Bulletin of the Oklahoma Anthropological Society, Volume XLI for 1993. Oklahoma Anthropological Society, Norman. 